\title{
Spanish version of the scale of attitudes toward alcohol, alcoholism and alcoholics: content validation
}

\author{
Versão espanhola da escala de atitudes frente ao álcool (eafaa): validação de conteúdo \\ Versión en español de la escala de actitudes frente al alcohol (EAFAA): validación de contenido
}

\section{Erika Gisseth León Ramírez', Divane de Vargas', Luz Patrícia Diaz Heredia", Alejandra Sepúlveda Corzo"I' \\ ' Universidade de São Paulo, School of Nursing, Graduate nursing program. São Paulo, Brazil. \\ "Universidad Nacional de Colombia, School of Nursing. Bogotá, Colômbia. \\ "' Hospital Simón Bolívar. Bogotá, Colômbia.}

How to cite this article:

León Ramírez EG, Vargas D, Diaz Heredia LP, Sepúlveda Corzo A. Spanish version of the scale of attitudes toward alcohol, alcoholism and alcoholics: content validation. Rev Bras Enferm [Internet]. 2017;70(2):342-8.

DOI: http://dx.doi.org/10.1590/0034-7167-2015-0149

\author{
Submission: 02-01-2016 Approval: 10-15-2016
}

\begin{abstract}
ABSTACT
Objective: to describe the process of translation and cultural adaptation of the scale of attitudes towards alcohol, alcoholism and alcoholics into the Spanish language. Methods: this was a methodological study, which followed the international guidelines for translation and adaptation of measurement scales. Results: During the process of translation and cultural adaptation of scale of attitudes towards alcohol, alcoholism and alcoholics to the Spanish language, the items were adjusted based on semantic, idiomatic and conceptual equivalence of the expressions contained in the scale of attitudes towards alcohol, alcoholism and alcoholics. Content validation indicated satisfactory validity indexes, with Intraclass Correlation Coefficient (ICC) (0.97), Content Validity Index (CVI) (0.92), and the Prevalence Adjusted Bias Adjusted Kappa (PABAK) (0.80). Conclusion: the scale of attitudes towards alcohol, alcoholism and alcoholics, adapted and translated into the Spanish language, presented content validity with satisfactory indexes, which affirmed that the instrument was adapted for the Colombian context. The next step will be evaluation of its psychometric properties in order to guarantee reliability for its use in Hispanic populations.
\end{abstract}

Descriptors: Scales; Psychological Tests; Validity of Tests; Attitude; Health Personnel.

\section{RESUMO}

Objetivo: descrever o processo de tradução e adaptação cultural da Escala de Atitudes Frente ao Álcool, ao alcoolismo e ao alcoolista para o idioma espanhol. Método: estudo metodológico, que seguiu as diretrizes internacionais para tradução e adaptação de escalas de mensuração. Resultado: durante o processo de tradução e adaptação cultural da EAFAA no idioma espanhol, os itens foram ajustados conforme avaliação das equivalências semântica, idiomática e conceitual das expressões contidas na EAFAA. A validação de conteúdo, indicou índices de validade satisfatórios com IVC $(0,97)$, PABAK $(0,80)$, ICC $(0,92)$. Conclusão: a EAFAA adaptada e traduzida para o idioma espanhol apresentou validade de conteúdo com índices satisfatórios, o que permite afirmar que se trata de um instrumento adequado ao contexto colombiano. O próximo passo será submeter a escala à avaliação das suas propriedades psicométricas com vistas a garantir a confiabilidade para seu uso em populações hispanofalantes.

Descritores: Escalas; Testes Psicológicos; Validade dos Testes; Atitude; Pessoal de Saúde.

\section{RESUMEN}

Objetivo: describir el proceso de traducción y adaptación cultural de la Escala de actitudes frente al alcohol, al alcoholismo y al alcohólico para el idioma español. Método: estudio metodológico, que siguió las directrices internacionales para la traducción y adaptación de escalas de medición. Resultado: durante el proceso de traducción y adaptación cultural de la EAFAA en idioma español, los ítems fueron ajustados de acuerdo a la evaluación de las equivalencias semántica, idiomática y conceptual de las expresiones contenidas en la EAFAA. La validación de contenido presentó índices de validez satisfactorios con IVC $(0,97)$, PABAK $(0,80)$, ICC $(0,92)$. Conclusión: la EAFAA adaptada y traducida para el idioma español, presentó validez de contenido con índices satisfactorios, lo que permite afirmar que se 
trata de un instrumento adecuado al contexto colombiano. El próximo paso será someter la escala a una evaluación de sus propiedades psicométricas, con el objetivo de garantizar la confiabilidad para su uso en poblaciones hispano-hablantes.

Descriptores: Escalas; Pruebas Psicológicas; Validez de las Pruebas; Actitud; Personal de Salud.

CORRESPONDING AUTHORＥrika Gisseth León RamírezＥ-mail: egleonr@usp.br

\section{INTRODUCTION}

Alcohol consumption accounts for $6.2 \%$ of deaths among men and $1.1 \%$ of deaths among women worldwide; among young people aged $15-29$, these rates reach $9 \%$. Globally, $36 \%$ of alcohol is consumed as beer, and consumption is much higher in Latin America, where the per capita rate is $54.7 \%{ }^{(1)}$. The most recent data indicate that $5.9 \%$ of world population deaths can be attributed to alcohol consumption, with some important differences between sex in relation to the proportion of overall alcohol-related deaths: $7.6 \%$ for men and $4.0 \%$ for women ${ }^{(2)}$.

In a comparative study among six Latin American countries, with a population between 15 and 64 years of age ${ }^{(3)}$, a variability in the levels of consumption among the populations studied was identified, which exceeded $50 \%$ in Argentina, Chile and Uruguay, $40 \%$ in Bolivia, and 35\% in Ecuador and Peru. In addition, the study found important data regarding abusive consumption, which reached $9 \%$ in Uruguay, $13 \%$ in Argentina, and $17 \%$ in Chile and Peru, and surpassed $40 \%$ in Ecuador and Bolivia.

Due to the high rates of alcohol abuse disorders in Latin Ameri$\mathrm{ca}$, health professionals are increasingly likely to work with people with alcohol-related disorders in their daily lives. In this sense, it is necessary to identify the attitudes of these professionals towards alcohol and the issues associated with their use, with evidence of the relationship between attitudes and interpersonal relationships in the work with users of alcohol and other drugs. Negative attitudes may influence a patient's withdrawal from treatment ${ }^{(4-5)}$.

Few studies are available on the attitudes of health professionals towards alcohol, alcoholism and the person with problems related to alcohol use, in the Spanish language, which can be caused in part by the lack of instruments available in that language to measure attitudes. The tools for this purpose are relevant in the context of nursing in Latin America, mainly because on this continent, Spanish is the official language in 21 countries, representing $90 \%$ of the region.

The research conducted to date ${ }^{(4,6)}$ regarding the attitudes of health professionals has used different measurement instruments and samples, showing similar results on the attitudes of health professionals; however, this may lead to biases in the interpretation of results and influence the comparison of the phenomenon in different world cultures. In addition, most of the available scales for measuring the attitudes of nurses towards the person with alcohol-related disorders are in the English language, and were therefore developed within that social and cultural context, lacking publications that present their processes of construction and validation, or even of translation for use in languages other than the language of origin.

Among the instruments available to measure nurses 'attitudes, only two were translated into Spanish ${ }^{(7-8)}$ : a scale based on the Nursing Education in Alcohol and Drug Education
$\left(\mathrm{NEADA}^{(8)}\right.$ and the Seaman-Manello scale - Nurses' Attitudes Towards Alcohol and Alcoholism Scale ${ }^{(7)}$. These instruments were developed more than a decade ago, which can demonstrate difficulties related to the differences in the population characteristics observed at the time they were developed, in contrast to the characteristics of the current population. These disadvantages point to the need to make available a new and more recent instrument, translated and validated for use among this population, that can measure several attitudinal dimensions, such as: behavioral, cognitive and emotional ${ }^{(9)}$.

Thus, the scale of attitudes towards alcohol, alcoholism and alcoholics - Escala de atitudes frente ao álcool, o alcoolismo e ao alcoolista (EAFAA) provides a more adequate option when compared to the scales currently available. It is a likert-type scale, composed of 50 items that are divided into four factors. Factor 1: Work and the interpersonal relations with patients with alcoholic disorders; Factor 2: The individual with alcoholrelated disorders; Factor 3: Alcoholism (Etiology); Factor 4: Alcohol beverages and its use ${ }^{(10)}$. This scale was developed a few years ago in a Latin American country, which presupposes that despite cultural differences, it is more similar to the characteristics of the target population of this study. Allied to this, the EAFAA has a rigorous methodological trajectory, which is available in academic publications, demonstrating good indexes of validity and reliability. Thus, the validation of the EAFAA is justified, in order to provide support for subsequent research that verifies the attitudes of Latin American professionals.

\section{OBJECTIVE}

To describe the process of cultural adaptation and content validation of the scale of attitudes towards alcohol, alcoholism and alcoholics- Escala de atitudes frente ao álcool, o alcoolismo e ao alcoolista (EAFAA), and the person with alcohol-related disorders to the Spanish language.

\section{METHOD}

\section{Ethical aspects}

The research ethics committee of the School of Nursing of the University of São Paulo approved the present study in 2014, as did the research committees of the institutions in which the data were collected. All participants signed the Terms of Free and Informed Consent.

\section{Study design}

The adaptation of the EAFAA was conducted with prior authorization of the author. The instrument was adapted to the Spanish language, in the Colombian culture, according to six steps suggested in the literature on the translation and 
adaptation guidelines of instruments, considered essential to obtain a quality result: translation, synthesis, back translation, evaluation of the version by a committee of judges, preparation of the preliminary version or pre-test version, and submission of documents produced at all stages for evaluation ${ }^{(11)}$.

\section{Process of cultural adaptation}

Most instruments to measure specific attributes such as attitude are developed in cultures or languages other than Spanish. In this sense, a cultural adaptation of the instrument in question is necessary, to guarantee the adequate use of language in terms of verbal expression and understanding of the population in which the instrument is intended to be administered $^{(11-14)}$. However, the translation process, with a rigorous evaluation of that process and cultural adaptation must be completed $^{(15)}$. As previously indicated, for the cultural adaptation of EAFAA, the methodology proposed by Beaton (2000) was used with the following stages.

\section{Step 1: Translation of the original instrument into the lan-} guage of the target population (Spanish)

Two bilingual translators performed the first step, each of them a native Spanish-speaker knowledgeable of the Brazilian language and culture. It is important to ensure that one of the translators completes a translation focused on the technical meaning, while the other completes a translation focused on the cultural meaning, to ensure the identification of ambiguous terminology and translation quality. The result of this process was the two translated versions, $\mathrm{T} 1$ and $\mathrm{T} 2^{(11)}$.

\section{Step 2: Synthesis of translation}

After the two translations, T1 and T2, a synthesis was obtained by means of a report prepared by the evaluator, together with a new version of the instrument (S1).

\section{Step 3: Back-translation}

The version developed in the previous step (S1) was translated back to the original language (Portuguese). This translation was performed by two individuals, who knew the specific terms of reference and whose native language was Portuguese, resulting in the synthesis of this version (S2), ensuring that the purpose of the scale was not lost in the translation.

\section{Step 4: Committee of judges}

A committee of six judges was invited to compose the panel of experts to evaluate the semantic, idiomatic, conceptual and experimental equivalence of each item, in addition to highlighting the representativeness, clarity and theoretical dimension of the items. The evaluations performed by the panel of experts were submitted to statistical tests to verify agreement, among them, the Content Validity Index (CVI), the Intraclass Correlation Coefficient (ICC) and the Prevalence Adjusted Bias Adjusted Kappa (PABAK).

\section{Step 5: Pilot study}

The version obtained in the previous stage was administered to a sample of 30 nurses who met the inclusion criteria: being a professional nurse; having clinical experience; Spanish as a native language, and working in one of the participating institutions (medium and large hospitals) in the Colombian capital, Bogota, DC. Participants in the pilot test were nurses assigned to Colombian health services, predominantly female $(80 \%)$, with an average age of 30 years, single $(63.3 \%)$, and without a graduate degree $(46.7 \%)$.

As indicated by the authors ${ }^{(11)}$, and in order to perform the semantic analysis of the items, that is, to verify if all items were comprehensible to the target population, the principal investigator contacted the subjects in their own work places. The subjects were asked to evaluate the EAFAA regarding to the understanding of the items and the difficulty in completing them. The Spanish version of the EAFAA, a sociodemographic data questionnaire, and a validation form with two dichotomous questions were answered: one that evaluated the comprehension of each item of the scale, and the second that evaluated the difficulty in completing the scale.

\section{Step 6: Submission of documents produced at all stages for evaluation}

In the final phase of the cultural adaptation, the documents produced in each of the stages described above were reviewed, to verify that all the steps indicated by the authors ${ }^{(11)}$ were performed satisfactorily, which is an indicator of a reasonable adaptation.

\section{RESULTS}

Some discrepancies were found in the translation and back translation process. For this reason, a consensus between the translators and the researchers was necessary to guarantee the use of the most adequate language for the instrument. After this process, the resulting version was submitted to the judges, which led to some suggestions regarding the equivalences of the items.

\section{Semantic equivalence}

The concept indicated for review was the word "alcool" (alcohol) because, within the culture of the target population, the word "alcohol" does not refer exclusively to alcoholic beverage, but also to other compounds used for different purposes. Thus, it was changed to "uso de bebida alcohólica - use of alcoholic beverage" in all items that contained the expression "uso de alcohol - alcohol consumption".

\section{Conceptual equivalence}

As indicated by the judges, the use of the word "persona" (person) was standardized as the subject that participates in the care relationship with the health professional. The word "cuidado" (caring) was used with caution, as the meaning could be interpreted in two contexts: as the care itself as an action of health care provided by the nurse; or as a precautionary alert. For this reason, the expression "Es preciso tener cuidado" (Care must be taken) (Item 46), "Es preciso tener cuidado para no ser agredido al trabajar com personas que tienen transtornos relacionados al uso de bebidas alcohólicas" (Care must be taken not to be assaulted when working 
with people who have disorders related to the use of alcoholic beverages) by the expression "debo tener precaución" (I must be cautious).

\section{Idiomatic equivalence}

Although $100 \%$ of the judges rated the instrument as adequate for idiomatic equivalence, it was difficult to achieve a consensus with the expression "bom senso" (good sense) (item 2); "Las personas com transtornos relacionados al uso de bebidas alcohólicas no tienen crítica de la realidad" (People with disorders related to the use of alcoholic beverages are not critical of reality) - since the expressions of the target culture indicated by the group of translators ("sentido comun" - common sense, "razonar bien" - reason well) did not fully explain the essence of the expression. After discussion with the judges via e-mail, and analysis of the options by the researchers, the expression "tener crítica de la realidad" (are critical of reality) was selected as the most indicated.

Table 1 - Results of the statistical tests applied in content validation of the scale of attitudes towards alcohol, alcoholism and alcoholics, Spanish version

\begin{tabular}{cccc}
\hline Test & Obtained value & \multicolumn{2}{c}{ Reference value } \\
\hline & Total $=0.97$ & \\
Content Validity & $\mathrm{R}=0.85$ & Valid, if a CVI of 0.80 was obtained \\
Index (CVI) & $\mathrm{C}=0.80$ & & \\
& $\mathrm{D}=0.89$ & Poor & 0 \\
Intraclass & $\mathrm{R}=0.92$ & Light & $0.021-0.20$ \\
Correlation & $\mathrm{C}=0.92$ & Regular & $0.21-0.40$ \\
Coefficient & $\mathrm{D}=0.91$ & Moderate & $0.61-0.60$ \\
(ICC) & & Substantial & $0.81-1.00$ \\
& & Almost perfect & \\
Prevalence & $\mathrm{R}=0.89$ & Values from -1 to +1 values above zero \\
Adjusted Bias & $\mathrm{C}=0.87$ & indicate a strong degree of agreement \\
Adjusted Kappa & $\mathrm{D}=0.76$ & when more than 1. \\
(PABAK) & & & \\
\hline
\end{tabular}

Note: $R=$ representativeness; $C=$ clarity; $D=$ theoretical dimension

Table 2 - A pilot study of the scale of attitudes towards alcohol, alcoholism and alcoholics, Spanish version, Bogotá, Colombia, 2015

\begin{tabular}{|c|c|c|c|c|c|c|}
\hline \multirow[t]{2}{*}{ Subjects } & \multirow[t]{2}{*}{$N=30$} & \multicolumn{2}{|c|}{$\begin{array}{l}\text { Question } 1 \text { (¿Para } \\
\text { usted los ítems de } \\
\text { la escala fueron } \\
\text { claros?) - The items } \\
\text { on the scale were } \\
\text { clear for you? }\end{array}$} & \multicolumn{2}{|c|}{$\begin{array}{l}\text { Question } 2 \text { ( } i \text { Tuvo } \\
\text { alguna dificultad } \\
\text { al diligenciar el } \\
\text { instrumento?) - Did } \\
\text { you have difficulty } \\
\text { in completing the } \\
\text { instrument? }\end{array}$} & \multirow[t]{2}{*}{$\begin{array}{c}\text { EAFAA } \\
\text { Mean score }\end{array}$} \\
\hline & & Sim & Não & Sim & Não & \\
\hline Men & 6 & $100 \%$ & $0 \%$ & $3 \%$ & $97 \%$ & 3.0 \\
\hline Women & 24 & $95 \%$ & $5 \%$ & $0 \%$ & $100 \%$ & 2.8 \\
\hline
\end{tabular}

Note: $E A F A A=$ Escala de Atitudes Frente ao Álcool (Scale of attitudes towards alcohol, alcoholism and alcoholics)
In addition to the qualitative evaluation, statistical tests were applied, aiming to establish a quantifiable and reliable measure regarding the representativeness $(R)$, clarity $(C)$ and theoretical dimension (D) of the items of the instrument, as shown below in Table 1.

The data suggested that the instrument had satisfactory content validity. However, when the indices of each item were calculated by factors, separately, and in each of the evaluated categories (representativeness [R], clarity $[\mathrm{C}]$ and theoretical dimension of factor [D]), some indices were below what is considered valid, 0.80). Among them, item number 29 of Factor 1 "Las personas con transtornos relacionados al uso de bebidas alcohólicas nunca aceptan lo que los profesionales de salud dicen sobre sus problemas con la bebida" (People with alcohol-related disorders never accept what health professionals say about their drinking problems) (0.67); and item number 42 of Factor 2 "El paciente con transtornos relacionados al uso de bebidas alcohólicas es una persona que le cuesta relacionarse con los otros" (The patient with disorders related to the use of alcoholic beverages is a person who has difficulty interacting with others) (0.33), regarding the items matching the factor.

According to the data obtained by the ICC and PABAK, the degree of agreement achieved was substantial; in other words, the proportion of agreement between the judges was greater than what would be expected to occur by chance.

After obtaining the content validity indexes, the EAFAA was submitted to a pilot study, with results shown in Table 2.

Once the proposed steps for the crosscultural adaptation of the EAFAA were completed, the scale was composed of a 49-item instrument (98\%) from the original version, considering that all items achieved good indexes with all statistical tests applied. Specifically, the of content validity index (0.97) showed that the scale was a valid instrument in terms of content, was clear and comprehensible, and able to be reproduced in the Spanish language.

\section{DISCUSSION}

This study proposed to validate the EAFAA content. During the process, the scale was translated and culturally adapted for the target population, a pilot test was performed with the adapted version of the scale to guarantee its semantic validity and, thus, to verify the content validity of the scale in its Spanish version.

In the cross-cultural adaptation and validation of the instrument content; $32 \%$ of the items required linguistic and structural changes classified by the members of the expert committee, according to the 
equivalence between the original instrument and the adapted version. These changes were analyzed in conjunction with the statistical tests (ICC, PABAK, CVI), which also provided adjustment and exclusion criteria for each EAFAA item.

In the translation and back- translation, "bom senso" (Common sense) in item 2, "Pessoas com transtornos relacionados ao uso do álcool não têm bom senso" (People with alcohol-related disorders do not have common sense) included in Factor 2, whose translation was "common sense", which generated disagreement between the two translators. For this reason, it was considered important to include a third evaluator in order to support further aid in the synthesis of translation processes. Finally, the expression was replaced by "crítica de la realidad" (critical of reality) and a simple translation of the expression was not enough. As studies indicate $^{(16-17)}$, it is necessary to verify that each term is adequate and comprehensible for the target population.

The presence of a third evaluator to resolve discrepancies between the two translators is poorly explained in published studies on instrument adaptation; however, the adoption of the third evaluator represents additional attention to reduce possible bias that would cause the loss of the essence of the original instrument, when translated incorrectly for the target population ${ }^{(11,18)}$.

When the content validity index (CVI) of the EAFAA was calculated, items with values lower than 0.7 were considered for exclusion or displacement, which resulted in the exclusion of item 20, "Beber con moderación no es prejudicial" (Drinking in moderation is not harmful) included in Factor 4; and, later, in the structural modification of item 28 of the same factor "Estoy a favor de beber com moderación" ( $\mathrm{am}$ in favor of drinking moderately) using the definitions indicated by the expert committee, which were based on World Health Organization guidelines ${ }^{(2,19)}$ regarding standards of alcohol use. This resulted in the item "Estoy a favor de beber com moderación" ( $\mathrm{am}$ in favor of moderate drinking), "Hombres, menos de 5 dosis en una ocasión. Mujeres, menos de 4 dosis en una occasion" (Men, less than 5 doses on one occasion; Women, less than 4 doses on one occasion), as well as clarifying the definitions of a standard dose as follows: dose $=1$ can of beer $-350 \mathrm{ml}, 1$ glass of wine- 140 $\mathrm{ml}, 1$ drink of liquor $-40 \mathrm{ml}, 1$ drink of aperitif $-40 \mathrm{ml}$.

According to the judges' suggestions and the CVI indicators, two items located in Factor 1 were moved to Factor 2, among them, item 42 "La persona con trastornos relacionados al uso de alcohol es una persona que le cuesta relacionarse con los otros" (The person with alcohol-related disorders is a person who has difficulty communicating with others) and item 15, "Lo que falta en una persona con trastornos relacionados al uso de alcohol es fuerza de voluntad" (What is missing in a person with alcohol related disorders is will power), because it was found that the content of the items referred to personal characteristics of the user, indicating a strong relation with the operational definition of Factor 2 .

Although item 14 "Pacientes con trastornos relacionados al uso de alcohol tienen mayores probabilidades de reaccionar en forma violenta contra mí" (Patients with alcohol-related disorders are more likely to react violently to me) and item 38, "De todos mis pacientes, el que posee trastornos relacionados al uso de alcohol es el más difícil de cuidar" (Of all my patients, those who have disorders related to alcohol use are the most difficult to care for), located in Factor 2, presented values considered appropriate for the content validity index, judges suggested that it was necessary to move them to Factor 1 ,"El trabajo y las relaciones interpersonales con personas con trastornos relacionados al uso de alcohol" (Work and interpersonal relationships with people with alcohol-related disorders). This suggestion was accepted because, when the conceptual matrix of the items resulting from the evaluation of the judges was analyzed, its content was adequate to the operational definition of the target factor, because the items refer to the interpersonal nurse- user relationship.

In contrast, other items that presented lower values in the CVI, such as item 29, "Las personas con trastornos relacionados al uso de bebidas alcohólicas nunca aceptan lo que los profesionales de salud dicen sobre sus problemas con la bebida" (People with alcohol-related disorders never accept what health professionals say about their drinking problems), included in Factor 1, with an index of 0.33 in the category that refers to the clarity of the item, remained unchanged due to the fact that the judges suggested a more thorough revision of their wording for further research. They stated that their understanding might be influenced by the social perception of alcohol use, which is a licit and socially accepted drug, and its use is seldom conceived as a problem, including by health professionals.

Although the content validity index is an important measure, and is frequently used in instrument validation studies to verify that agreement of the judges with the parameters evaluated in the items did not happen by chance, the authors ${ }^{(20-21)}$ highlight that the CVI should not be considered as the only test to determine content validity, questioning the fact that it is based on correlation indexes between the judges, representing the tendency to make the same judgments about some items.

Given this postulate, other statistical tests were applied, to verify the degree of agreement between the judges that composed the committee of experts: among them the ICC and the PABAK. The data obtained indicated that the degree of agreement was substantial, that is, that the proportion of agreement between the judges was greater than could be expected if the agreement in their answers occurred randomly.

To finalize the cultural adaptation and content validation step, the adapted version of the EAFAA was submitted to a pilot study, whose results indicating a 95\% understandable rating for the items, guaranteeing their comprehension among the target population, as recommended by specialized authors on the subject $t^{(11,22)}$.

\section{Study limitations}

The study was conducted in a specific region of Latin America, limited to the specific characteristics of some Colombian cities, which may in fact have cultural similarities with other regions of the country and the continent. In addition, the sample consisted solely of nurses and, although this was the target population of the study, it is recommended to administer the scale to other categories of professionals, because caring for a person with problems resulting from alcohol use involves the work of members of a multidisciplinary team. 


\section{Contributions to the nursing field}

The translation, adaptation and validation of the EAFAA content for the Spanish language, represents a breakthrough in knowledge as it provides a scale for use in that language. Ultimately, this study can support subsequent research that assesses the attitudes of health professionals in Spanishspeaking populations, making it possible to recognize differences and similarities between attitudes across Latin American cultures. The use of a single instrument will certainly offer greater reliability of the results obtained, independent of the culture, helping develop a body of knowledge about the attitudes of these professionals, which remains incipient in Latin America.

\section{CONCLUSION}

The process of cultural adaptation and content validation of the EAFAA resulted in an instrument with 49 items, distributed into four factors, according to the original scale distribution, valid in relation to the semantic, idiomatic and conceptual equivalence and, therefore, capable of evaluating nurses' attitudes when administered in the Colombian culture.

\section{FUNDING}

The present study was financially supported by the Amparo Research Foundation of the State of São Paulo - Fundação Amparo à Pesquisa do Estado de São Paulo, by means of a master's degree scholarship - process No. 2013/24983-3.

\section{ACKNOWLEDGEMENTS}

To the institutions, Simón Bolívar Hospital (Colombia), Santa Clara Hospital (Colombia), and Saludcoop (Colombia), and to the participating nurses, for allowing the data collection to conduct this research.

\section{REFERENCES}

1. World Health Organization. Global status report on alcohol and health. OMS. 2011.

2. World Health Organization. Global Status Report on alcohol and health [Internet]. OMS. 2014[cited 2015 Mar 11]. Available from: http:// apps.who.int/iris/bitstream/10665/112736/1/9789240692763_eng.pdf

3. CICAD. Elementos orientadores para las políticas públicas sobre drogas en la subregión. 2008.

4. Crothers E. Determinants of Nurses' Attitudes toward the Care of Patients with Alcohol Problems. ISRN Nurs. 2011;2011:11.

5. Tsai Y-F, Tsai M-C, Lin Y-P, Weng C-E, Chen C-Y, Chen M-C. Facilitators and barriers to intervening for problem alcohol use. J Adv Nurs[Internet]. 2010 Jul[cited 2013 Jun 14];66(7):1459-68. Available from: http://www.ncbi.nlm.nih.gov/pubmed/20492022

6. Iqbal N, McCambridge O, Edgar L, Young C, Shorter GW. Health-care professionals' attitudes across different hospital departments regarding alcohol-related presentations. Drug Alcohol Rev[Internet]. 2015 [cited 2015 Feb 20]. Available from: http://www.ncbi.nlm.nih. gov/pubmed/25693922

7. Navarrete PR, Villar M. Actitud de la enfermera de un complejo hospitalario en relación al paciente alcohólico. Rev Latino-Am Enfermagem. 2004;12:420-6.

8. Vásquez E, Pillon SC. La formación de enfermeras y el fenómeno de las drogas en Colombia: conocimientos, actitudes y creencias. Rev Latino-Am Enfermagem[Internet]. 2005[cited 2015 Feb 15];13(spe):845-53. Available from: http://www.scielo.br/pdf/ rlae/v13nspe/v13nspea12.pdf

9. Vargas D De. A construção de uma escala de atitudes frente ao álcool, ao alcoolismo e ao alcoolista: um estudo psicométrico. Universidade de São Paulo Escola de Enfermagem de Riberão Preto; 2005.

10. Vargas D. Validação de construto da Escala de Atitudes Frente ao Álcool, ao Alcoolismo e a Pessoas com Transtornos Relacionados ao Uso do Álcool. Rev Psiquiatr Clin. 2014;55(11).

11. Beaton D, Bombardier C, Guillemin F, Ferraz M. Guidelines for the Process of Cross-Cultural Adaptation of Self-Report Measures. Spine: Philadelphia; 1976;2000;25(24):3186-91.

12. Maneesriwongul W, Dixon JK. Instrument translation process: a methods review. J Adv Nurs[Internet]. 2004 [cited 2015 Mar 18];48(2):175-86. Available from: http://doi.wiley.com/10.1111/j.1365-2648.2004.03185.x

13. Comittee for translations and Protocols International RDC/TMD Consortium Network. Guidelines for Establishing Cultural Equivalency of Instruments. Buffalo; 2013.

14. Beaton D, Bombardier C, Guillemin F, Ferraz MB. Recommendations for the Cross-Cultural Adaptation of Health Status Measures. 1998.

15. Lage LV, Levy RA, Ciconelli RM. Instrumentos de avaliação em reumatologia: importância de sua tradução e validação para nosso idioma. Rev Bras Reumatol[Internet]. 2006[cited 2015 Mar 18];46(4):237. Available from: http://www.scielo.br/pdf/rbr/v46n4/31817.pdf

16. Rubio DM, Berg-Weger M, Tebb SS, Lee ES, Rauch S. Objectifying content validity: Conducting a content validity study in social work research. Soc Work Res[Internet]. 2003[cited 2015 May 15];27(2):94-104. Available from: http://swr.oxfordjournals.org/ content/27/2/94.short

17. Alexandre NM, Coluci MZ. Validade de conteúdo nos processos de construção e adaptação de instrumentos de medidas. Ciênc Saude 
Colet[Internet]. 2011[cited 2015 Mar 18];16(7):3061-8. Available from: http://www.scielo.br/pdf/csc/v16n7/06.pdf

18. Pasquali L. Instrumentação Psicológica: Fundamentos e práticas. 2010 8ª ed. Artmed, editor. São Paulo; 2010. 183 p.

19. National Institute on Alcohol Abuse and Alcoholism. Drinking Levels Defined. 2014.

20. Beckstead JW. Content validity is naught. Int J Nurs Stud[Internet]. 2009[cited 2015 Mar 18];46(9):1274-83. Available from: http://www. sciencedirect.com/science/article/pii/S0020748909001576

21. Claro H. Translation and cultural adaptation of the Global Appraisal of Individual Needs - Initial. Rev da Esc Enferm da USP[Internet]. 2012[cited 2015 May 15];46(5):1148:55. Available from: http://www.scielo.br/pdf/reeusp/v46n5/en_16.pdf

22. Sousa V, Rojjanasrirat W. Translation, adaptation and validation of instruments or scales for use in cross-cultural health care research: a clear and user-friendly guideline. J Eval Clin Pract[Internet]. 2011[cited 2015 May 15];17(2):268-74. Available from: http://www.ncbi.nlm.nih.gov/pubmed/20874835 